\title{
Prevalence of antiphospholipid antibodies in patients with fetal loss
}

\author{
Henk Jan Out, Hein W Bruinse, Godelieve C M L Christiaens, Marja van Vliet, \\ Jan F: Meilof, Philip G de Groot, Ruud J T Smeenk, Ronald H W M Derksen
}

\begin{abstract}
The prevalence of antiphospholipid and antinuclear antibodies in 102 patients with at least three unexplained miscarriages before a gestational age of 12 weeks, or at least one intrauterine fetal death after 12 weeks, was investigated and compared with the prevalence in 102 normal pregnant controls. Six patients had a history of thrombosis and six had 'lupus-like' disease.

Twenty one patients had anticardiolipin antibodies compared with 10 controls. Serum samples of nine patients and one control contained antinuclear antibodies. The lupus anticoagulant was present in the plasma of five patients with anticardiolipin antibodies. The influence of patient selection on the results was illustrated by the finding that antiphospholipid antibodies and antinuclear antibodies were mainly detected in patients with lupus-like disease or a history of thrombosis. When these patients were excluded there was no significant difference in the prevalence of anticardiolipin and antinuclear antibodies between patients and controls.
\end{abstract}

Therefore, in the absence of lupus-like disease or a history of thrombosis, screening for antiphospholipid antibodies in patients with adverse pregnancy outcomes seems not to be indicated.

The presence of antiphospholipid antibodies, such as anticardiolipin antibodies and the lupus anticoagulant, is significantly associated with a history of thrombosis, thrombocytopenia, recurrent miscarriages, and late fetal death. ${ }^{1}$ These antibodies are predominantly found in patients with systemic lupus erythematosus, but they also have been described in patients with other rheumatic diseases, or apparently healthy persons with fetal wastage as the only symptom. ${ }^{2}$ The prevalence of antiphospholipid antibodies in women with fetal loss in the absence of systemic lupus erythematosus is not known and it varies in different reports from 8 to $50 \%$ for anticardiolipin antibodies and from 3 to $48 \%$ for the lupus anticoagulant. ${ }^{3-11}$

We investigated the prevalence of antiphospholipid antibodies in 102 patients with fetal loss without concomitant connective tissue disease, according to the criteria of the American Rheumatism Association. These patients were also screened for the presence of antinuclear antibodies, antibodies to extractable nuclear antigens, and antibodies to double stranded DNA.

\section{Patients and methods}

PATIENTS

In the Netherlands a multicentre trial on the treatment of pregnant patients with antiphospholipid antibodies is currently being conducted. ${ }^{12}$ To obtain eligible patients specialists all over the country are encouraged to send blood samples of women with at least three unexplained spontaneous miscarriages before a gestational age of 12 weeks, or at least one unexplained intrauterine fetal death after 12 weeks, for determination of the lupus anticoagulant and anticardiolipin antibodies. This report deals with the first 102 screened women; table 1 gives their main characteristics. None of these patients fufilled the American Rheumatism Association criteria for systemic lupus erythematosus ${ }^{13}$ or other connective tissue diseases, as assessed by a questionnaire, in which clinical and haematological symptoms of autoimmune disease and the occurrence of thrombosis in the past had to be completed by the referring specialist.

According to this questionnaire six patients had symptoms suggestive of a 'lupus-like' disease (table 2). These symptoms included arthralgia (three patients), Raynaud's phenomenon (two), photosensitivity (one), dermal vasculitis (one), haemolytic anaemia (one), leucocytopenia (one), and thrombocytopenia (four).

Six patients, including one with lupus-like disease, had a history of thrombosis: one had a cerebrovascular accident and five had deep venous thrombosis, complicated in three patients by pulmonary embolism. The 24 women with only miscarriages before 12 weeks (table 1) had normal blood sugar values and thyroid functions, normal parental karyotypes, and no abnormalities on hysterosalpingography.

\section{CONTROL GROUP}

The control group comprised 102 pregnant women with at least one successful pregnancy

Table 1 Characteristics of the study groups

\begin{tabular}{lcc}
\hline & $\begin{array}{c}\text { Patients } \\
(n=102)\end{array}$ & $\begin{array}{c}\text { Controls } \\
(n=102)\end{array}$ \\
\hline Median age (SD) (years) & $32(4 \cdot 8)$ & $30(5 \cdot 9)$ \\
Range & $18-41$ & $17-45$ \\
Number of SM* $<12$ weeks & 236 & 0 \\
Number of IUFD* $>12$ weeks & 78 & 0 \\
Number of live births & 59 & 194 \\
Only SM & 24 & 0 \\
Only IUFD & 36 & 0 \\
Both SM and IUFD & 42 & 0 \\
\hline *SM=spontaneous miscarriages & $(<12$ weeks); & IUFD $=$
\end{tabular}

intrauterine fetal death ( $\geqslant 12$ weeks).
Medicine, Division of

Immunopathology, University

PO Box 85500 ,

3508 GA Utrecht,

Accepted for publication

4 July 1990 
Table 2 Characteristics of six patients with lupus-like disease

\begin{tabular}{|c|c|c|c|c|c|c|c|c|c|}
\hline \multirow{2}{*}{$\begin{array}{l}\text { Case } \\
\text { No }\end{array}$} & \multicolumn{2}{|c|}{$A C A^{*} \dagger$} & \multirow[t]{2}{*}{$L A C^{*}$} & \multirow[t]{2}{*}{$A N A^{*}$} & \multirow[t]{2}{*}{$E N A^{*}$} & \multirow[t]{2}{*}{$S M^{*}$} & \multirow[t]{2}{*}{$I U F D^{*}$} & \multirow{2}{*}{$\begin{array}{l}\text { History of } \\
\text { thrombosis }\end{array}$} & \multirow{2}{*}{$\begin{array}{l}\text { Lupus-like } \\
\text { symptoms }\end{array}$} \\
\hline & $I g G$ & IgM & & & & & & & \\
\hline $\begin{array}{l}1 \\
2\end{array}$ & $\begin{array}{l}++ \\
+\end{array}$ & $\overline{t+}$ & $\begin{array}{l}+ \\
+\end{array}$ & + & $\begin{array}{l}+ \\
-\end{array}$ & $\begin{array}{l}6 \\
0\end{array}$ & $\begin{array}{l}2 \\
2\end{array}$ & $\overline{-}$ & $\begin{array}{l}\text { Thrombocytopenia, leucocytopenia } \\
\text { Arthralgia, Raynaud's phenomenon, } \\
\text { thrombocytopenia }\end{array}$ \\
\hline $\begin{array}{l}3 \\
4 \\
5 \\
6\end{array}$ & $\begin{array}{l}+ \\
+ \\
+\end{array}$ & $\begin{array}{l}- \\
\overline{+} \\
-\end{array}$ & $\begin{array}{l}+ \\
+ \\
+\end{array}$ & $\begin{array}{l}+ \\
+ \\
+\end{array}$ & $\begin{array}{l}+ \\
- \\
-\end{array}$ & $\begin{array}{l}\mathbf{0} \\
\mathbf{0} \\
0 \\
0\end{array}$ & $\begin{array}{l}1 \\
1 \\
1 \\
1\end{array}$ & $\begin{array}{l}- \\
- \\
+ \\
-\end{array}$ & $\begin{array}{l}\text { Thrombocytopenia } \\
\text { Arthralgia, photosensitivity } \\
\text { Haemolytic anaemia } \\
\text { Raynaud's phenomenon, dermal vasculitis, }\end{array}$ \\
\hline
\end{tabular}

*ACA=anticardiolipin antibodies; LAC=lupus anticoagulant; ANA=antinuclear antibodies; ENA=extractable nuclear antigens; SM=spontaneous miscarriages ( $<12$ weeks); IUFD =intrauterine fetal death $(\geqslant 12$ weeks).

SM=spontaneous miscarriages $(<12$ weeks); IUFD $=$ intrauterine fetal death
$t-=$ negative; $+=$ low positive; $++=$ medium positive; $+++=$ high positive.

and no history of spontaneous miscarriage or intrauterine fetal death. These women were retrospectively screened for anticardiolipin antibodies and antinuclear antibodies by examination of serum samples obtained at their first antenatal visit, usually during the first trimester. Recent studies have indicated that there is no influence of pregnancy on antinuclear antibody and anticardiolipin antibody expression. ${ }^{14-16}$

\section{ASSAYS \\ Lupus anticoagulant}

Blood samples for determination of the lupus anticoagulant were taken by venepuncture into a 0.1 volume of $3.8 \%$ trisodium citrate. Platelet poor plasma was prepared by centrifuging the blood twice at $4^{\circ} \mathrm{C}$ and $2000 \mathrm{~g}$ for 15 minutes. Three assays on platelet poor plasma were performed for demonstration of the lupus anticoagulant, as described previously. ${ }^{17}$ Samples were considered positive for the lupus anticoagulant when at least two of the three following criteria were fulfilled: $(a)$ a prolonged partial thromboplastin time in a 1:1 mixture of patient and pooled normal plasma using thromboplastin derived from human brain; $(b)$ a progressive increase in the partial thromboplastin time of test plasma upon dilution of thromboplastin; and (c) a raised kaolin clotting time index, calculated from the kaolin clotting time of control and test plasma mixed at different ratios.

\section{Anticardiolipin antibodies}

Anticardiolipin antibodies (IgG and IgM) were measured in serum by an enzyme linked

Table 3 Autoantibodies in patients with fetal loss and in controls. Results are given as number (percentage)

\begin{tabular}{|c|c|c|c|c|}
\hline \multirow[t]{2}{*}{ Antibody } & \multicolumn{3}{|l|}{ Patients } & \multirow{2}{*}{ - $\begin{array}{c}\text { Controls } \\
(n=102)\end{array}$} \\
\hline & $\begin{array}{l}\text { Total } \\
(n=102)\end{array}$ & $\begin{array}{l}\text { Only fetal } \\
\text { loss } \\
(n=91)\end{array}$ & $\begin{array}{l}\text { Fetal loss } \\
+L L D^{*} / \text { thrombosis } \\
(n=l l)\end{array}$ & \\
\hline $\begin{array}{l}\text { ACA }^{*} \\
\text { LAC* } \\
\text { ANA* } \\
\text { Anti-ENA* } \\
\text { Anti-dsDNA* }\end{array}$ & $\begin{aligned} 21 & (21) \\
5 & (5) \\
9 & (9) 5 \\
2 & (2) \\
1 & (1)\end{aligned}$ & $\begin{array}{cc}13 & (14) \\
0 & \\
3 & (3) \\
0 & \\
1 & (1)\end{array}$ & $\begin{array}{l}8(73) \dagger \\
5(45) \dagger \\
6(55) \\
2(18) 9 \\
0\end{array}$ & $\begin{array}{l}10(10) \ddagger \\
\text { ND }^{*} \\
1(1) \| \\
\text { ND } \\
\text { ND }\end{array}$ \\
\hline
\end{tabular}

*Anti-dsDNA=anti-double-stranded DNA; LLD=lupus-like disease; ND=not done; for other abbreviations see table 2 .

†Antiphospholipid antibodies in patients with only fetal loss $v$ lupus-like disease/thrombosis;

† Antiphospholipid antibodies in patients with only fetal loss $v$ lupus-like disease/thrombosis;
$\ddagger$ Anticardiolipin antibodies, patients $v$ controls; $p=0.025$ ( $p=0.230$ after exclusion of patients with †Anticardiolipin antibodies, patien

lupus-like disease/thrombosis). pholipid antibodies; $p=0.017$

Antinuclear antibodies in patients $v$ controls; $p=0.009$ ( $p=0.269$ after exclusion of patients with upus-like disease/thrombosis)

ISpecificity: anti-(Ro)SSA. immunosorbent assay (ELISA) according to the procedure described by Derksen et al. ${ }^{17}$ The anticardiolipin antibody titre was expressed in units $/ \mathrm{ml}$. The value of a standard sample was chosen arbitrarily as 100 units anticardiolipin antibodies $/ \mathrm{ml}$. A positive result indicated a value in units more than $2 \mathrm{SD}$ above the value obtained with pooled control serum derived from 71 healthy volunteers, tested on six different occasions. Positive results were graded according to criteria agreed upon at the international workshop on standardisation of the anticardiolipin antibody assay in London $^{18}$ : for IgG anticardiolipin antibodies low positive (mean (2SD)) (units/ml <80); medium positive (80<units/ml < 185 ); high positive (units $/ \mathrm{ml}$ $>185$ ); for IgM anticardiolipin antibodies low positive (mean (2SD)) (units/ml $<25$ ); medium positive $(25<$ units/ml $<200)$; high positive (units/ml $>200$ ).

\section{Other serological parameters}

Antinuclear antibodies were assayed by indirect immunofluorescence, essentially as described by Tan, ${ }^{19}$ with slide preparations of HEp- 2 cells as the substrate and serum samples in a 1:40 dilution.

Antibodies to extractable nuclear antigens were detected as described by Kurata and Tan. ${ }^{20}$ This assay used an extract of rabbit thymus powder (Pel Freez, Arkansas), or bovine spleen extract as the source of antigen. Confirmation of an observed reactivity as antiribonucleoprotein, anti-Sm, anti-(La)SSB, or anti-(Ro)SSA was achieved by comparison with reference sera (Arthritis Foundation, CDC, Atlanta).

Antibodies to double stranded DNA were detected by indirect immunofluorescence on Crithidia luciliae. ${ }^{21}$

\section{STATISTICS}

All p values were calculated with Fisher's exact test. Values below 0.05 were considered significant.

\section{Results}

ANTIPHOSPHOLIPID ANTIBODIES

Anticardiolipin antibodies were found in 21 patients $(21 \%)$ and 10 controls (10\%) (table 3$)$; this difference was significant $(p=0.025)$. Five patients were positive for the lupus anticoagulant; all five also had anticardiolipin anti- 
Table 4 Distribution of anticardiolipin antibody isotypes in patients and controls

\begin{tabular}{|c|c|c|c|c|c|}
\hline \multicolumn{2}{|c|}{ Anticardiolipin antibodies } & \multicolumn{3}{|c|}{ Patients } & \multirow{2}{*}{$\begin{array}{l}\text { Controls } \\
(\boldsymbol{n})\end{array}$} \\
\hline$I g G$ & $\operatorname{Ig} M$ & $\begin{array}{l}\text { Total } \\
(n)\end{array}$ & $\begin{array}{l}\text { Only fetal } \\
\text { loss } \\
(n)\end{array}$ & $\begin{array}{l}\text { Fetal loss }+ \\
L L D^{*} / \text { thrombosis } \\
(n)\end{array}$ & \\
\hline $\begin{array}{l}+ \\
+ \\
-\end{array}$ & $\begin{array}{l}- \\
+ \\
+ \\
-\end{array}$ & $\begin{array}{r}5 \\
13 \\
3 \\
81\end{array}$ & $\begin{array}{r}2 \\
11 \\
0 \\
78\end{array}$ & $\begin{array}{l}3 \dagger \\
2 \\
3 \ddagger \\
3\end{array}$ & $\begin{array}{r}1 \\
8 \\
1 \\
92\end{array}$ \\
\hline Total & & 102 & 91 & 11 & 102 \\
\hline
\end{tabular}

- LLD=lupus-like disease.

†Two also had the lupus anticoagulant.

¥All three had the lupus anticoagulant. bodies. Antiphospholipid antibodies were more commonly detected in patients with only intrauterine fetal death after 12 weeks (anticardiolipin antibodies $6 / 36(17 \%)$, the lupus anticoagulant $4 / 36(11 \%)$ ) than in patients with only spontaneous miscarriages (anticardiolipin antibodies $3 / 24(13 \%)$, the lupus anticoagulant $1 / 24(4 \%))$. These differences did not reach statistical significance, however.

Four of the six patients with lupus-like disease had the lupus anticoagulant and anticardiolipin antibodies, and one had only anticardiolipin antibodies (table 2). Of six patients with a history of thrombosis (including one patient with lupus-like disease), four had antiphospholipid antibodies (all had anticardiolipin antibodies and two had the lupus anticoagulant). The prevalence of antiphospholipid antibodies in the 11 patients with lupus-like disease or a history of thrombosis, or both, was significantly higher than in patients with fetal loss as the only symptom ( $p<0.001$, table 3$)$.

Raised anticardiolipin antibody titres were found in $13 / 91(14 \%)$ patients with only fetal loss and without lupus-like disease or thrombosis compared with raised titres in 10/102 $(10 \%)$ controls. This difference was not significant $(p=0.230)$.

Table 4 gives the isotypes of anticardiolipin antibodies in patients and controls. The vast majority of anticardiolipin antibody positive reactions were caused by the IgM isotype; 13/21 $(62 \%)$ patients and $8 / 10(80 \%)$ controls only had raised IgM anticardiolipin antibodies. In contrast, of eight patients positive for antiphospholipid antibodies with lupus-like disease or thrombosis, only two (25\%) had raised titres of the IgM isotype alone. All five patients positive for the lupus anticoagulant showed anticardiolipin antibodies of the IgG isotype. Three of these also had anticardiolipin antibodies of the IgM isotype.

Anticardiolipin antibody titres were mainly low positive: $14 / 16(88 \%)$ patients with IgM anticardiolipin antibodies had low positive titres, one had medium and one had a high positive titre. Both patients with medium and high positive IgM anticardiolipin antibodies showed the lupus anticoagulant. Of eight patients positive for the IgG isotype, five $(63 \%)$ had low positive titres and three $(38 \%)$ had medium positive titres. Two of the three patients with medium positive titres had the lupus anticoagulant. Raised anticardiolipin antibody titres in the control group were all low positive.
ANTINUCLEAR ANTIBODIES, EXTRACTABLE NUCLEAR ANTIGENS AND ANTI-

DOUBLE-STRANDED DNA

Nine patients $(9 \%)$ and one control $(1 \%)$ had antinuclear antibodies (1/40 or more, $p=0.009$, table 3). Of the nine patients positive for antinuclear antibodies, five had lupus-like disease, one had a history of thrombosis, three had anticardiolipin antibodies plus the lupus anticoagulant, and two had only anticardiolipin antibodies. The control who was positive for antinuclear antibodies did not show antiphospholipid antibodies. There was a significant correlation between the presence of antiphospholipid antibodies and antinuclear antibodies in the patients $(p=0.017)$.

When patients with lupus-like disease or thrombosis were excluded the prevalence of antinuclear antibodies in patients (3/91) was not significantly higher than that in the control group $(1 / 102, p=0 \cdot 269)$.

Two patients had antibodies to extractable nuclear antigens (specificity (Ro)SSA, table 3). Both had lupus-like disease and were positive for antinuclear antibodies, the lupus anticoagulant, and anticardiolipin antibodies. No congenital heart block had been noted in previous pregnancies of these patients. There were no patients with anti-RNP, anti-Sm, or anti-(La)SSB antibodies.

One patient without lupus-like disease or thrombosis showed antibodies to double stranded DNA. She had a third trimester intrauterine death. Anticardiolipin antibodies were low positive for IgM. Antinuclear antibodies and antibodies to extractable nuclear antigens could not be shown.

\section{Discussion}

This study shows an antiphospholipid antibody prevalence of $21 \%$ for anticardiolipin antibodies and $5 \%$ for the lupus anticoagulant in a group of 102 patients with at least three spontaneous miscarriages before a gestational age of 12 weeks, or with at least one intrauterine fetal death after 12 weeks. Table 5 shows the wide range of antiphospholipid antibody prevalences in patients with fetal loss and no underlying disorder, as found in nine studies, with values ranging from 8 to $50 \%$ for anticardiolipin antibodies and from 3 to $48 \%$ for the lupus anticoagulant. Identification of patients positive for antiphospholipid antibodies is of importance because several reports have described successful pregnancies in patients with antiphospholipid antibodies, treated during pregnancy. ${ }^{22} 23$

This study provides an explanation for the wide variation in prevalence reported for antiphospholipid antibodies by showing that the prevalences of anticardiolipin antibodies and the lupus anticoagulant decreased from 21 to $14 \%$ and from 5 to $0 \%$, respectively, after exclusion of all patients with symptoms suggestive of a lupus-like disease or a history of thrombosis, or both, known to be associated with antiphospholipid antibodies. Moreover, when these patients were excluded, the significant difference initially found between anticardiolipin antibodies in patients and controls 
Table 5 Studies on the prevalence of antiphospholipid antibodies in patients with fetal loss

\begin{tabular}{|c|c|c|c|c|c|}
\hline References & $\begin{array}{l}\text { Patients } \\
(n)\end{array}$ & $\begin{array}{l}\text { Inclusion } \\
\text { criteria }\end{array}$ & $\begin{array}{l}\text { Lupus } \\
\text { anticoagulant } \\
\text { assay }\end{array}$ & $\begin{array}{l}\text { Lupus } \\
\text { anticoagulant } \\
\text { positive } \\
\text { No }(\%)\end{array}$ & $\begin{array}{l}\text { Anticardiolipin } \\
\text { antibody } \\
\text { positive } \\
\text { No }(\%)\end{array}$ \\
\hline Carreras et $a l^{4}$ & 24 & $\begin{array}{l}\text { At least } 3 \mathrm{SM}^{*}<20 \text { wks, at least } \\
2 \text { IUGR }^{*}\left(<\mathrm{P}_{3}\right) \text {, at least } 1 \text { IUFD } \\
>20 \text { wks }\end{array}$ & APTT $^{*}$, PT $^{*}$ TTI $^{*}$ & $2(8)$ & ND \\
\hline 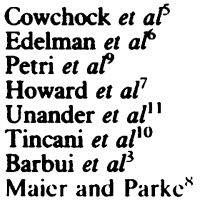 & $\begin{array}{r}61 \\
130 \\
44 \\
29 \\
99 \\
103 \\
49 \\
20\end{array}$ & $\begin{array}{l}\text { At least } 2 \text { pregnancy losses } \\
\text { More than } 2 S M \text { in lst or } 2 \text { nd trimester } \\
\text { At least } 3 S M \text { in lst or } 2 \text { nd trimester } \\
\text { More than } 3 S M \text { or stillbirths } \\
\text { At least } 3 S M \text { in lst or } 2 \text { nd trimester } \\
\text { At least } 3 S M \text { or one or more IUFD } \\
\text { At least } 2 \text { early abortions } \\
\text { At least } 3 \text { uncxplaincd abortions } \\
<20 \text { wecks }\end{array}$ & $\begin{array}{l}\text { RVVT* } \\
\text { APTT, TTI, PNP* } \\
\text { APTT, RVVT } \\
\text { APTT, PT, DSTT } \\
\text { ND* } \\
\text { Not specified } \\
\text { APTT, KCT* TTI } \\
\text { APTT. PNP }\end{array}$ & 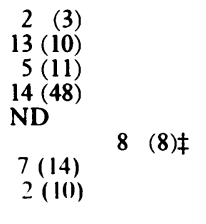 & $\begin{array}{l}8(13) \\
\text { ND } \\
5(11) \\
\text { NDt } \\
42(42) \\
4(8) \\
10(50)\end{array}$ \\
\hline
\end{tabular}

${ }^{*} \mathrm{SM}=$ spontaneous miscarriages; IUGR = intrauterine growth retardation; IUFD=intrauterine fetal death; APTT=activated partial thromboplastin time; PT $=$ prothrombin time; TTI =tissue thromboplastin inhibition test; $R V V T=$ Russell's viper venom time; $P N P=$ platelet neutralisation procedure; DSTT=dilute simplastin time test; $\mathrm{ND}=$ not done, $\mathrm{KCT}=$ kaolin clotting time.

tAn anticardiolipin antibody enzyme linked immunosorbent assay (ELISA) was done in four of 14 patients positive for the lupus anticoagulant. In all cases the results were negative.

†The lupus anticoagulant and anticardiolipin antibodies were considered together.

$(p=0.025)$ disappeared. These patients were identified by clinical data and routine haematological investigations. Lupus-like symptoms included arthralgia, Raynaud's phenomenon, dermal vasculitis, photosensitivity, haemolytic anaemia, leucocytopenia, and thrombocytopenia. In the presence of thrombocytopenia, especially, there was a high prevalence of antiphospholipid antibodies: all four patients with thrombocytopenia had anticardiolipin antibodies and three had the lupus anticoagulant. Therefore, inclusion of such patients in studies on the prevalence of antiphospholipid antibodies in patients with fetal loss might result in an overestimation of the occurrence of these antibodies.

The conflicting results of antiphospholipid antibody screening can also be explained by differences in laboratory techniques. The lack of international uniformity for the definition of the lupus anticoagulant is illustrated by the use of seven different lupus anticoagulant assays (table 5). International agreement on this issue is therefore urgently needed. Differences in normal cut off levels (ranging from 2 to 5SD above the mean) may in part account for the varying anticardiolipin antibody prevalences.

Positive anticardiolipin antibody titres in the absence of the lupus anticoagulant were usually low positive and of IgM isotype (13/16 patients, $8 / 10$ controls). Possibly, these findings reflect a background non-specific binding in the ELISA. It is known that such binding might be responsible for low positive IgM anticardiolipin antibody titres. ${ }^{24}$ The IgG isotype seems more important as it was shown by all patients positive for the lupus anticoagulant. Furthermore, low positive anticardiolipin antibody values in the absence of the lupus anticoagulant were found in only three patients (3\%). Also, anticardiolipin antibody titres discriminate between different patient groups, and we found that medium or high positive anticardiolipin antibody titres only occurred in the group of patients with lupus-like disease or a history of thrombosis, or both.

We found nine patients $(9 \%)$ with antinuclear antibodies (1/40 or more) compared with one antinuclear antibody positive control $(p=0.009)$. Of interest is the observation that antinuclear antibodies were present in 3/91 (3\%) patients with only fetal loss, but in $6 / 11(55 \%)$ of those with lupus-like disease or thrombosis, or both. Antiphospholipid and antinuclear antibodies were significantly associated in the patients $(p=0.017)$. Also, both patients with antibodies to extractable nuclear antigens had antiphospholipid antibodies and antinuclear antibodies. As with the antiphospholipid antibodies the significant correlation initially found between fetal loss and antinuclear antibodies $(p=0.009)$ was lost upon exclusion of the 11 patients with lupus-like disease or thrombosis, or both, in the past $(p=0.269)$.

In conclusion, screening for antiphospholipid antibodies in women with recurrent unexplained miscarriages or late fetal death seems not to be indicated unless there is a history of thrombosis or presence of symptoms that might suggest more widespread systemic disease. Doctors should be alert to such symptoms and search for these before advanced immunological laboratory tests are carried out. If lupus-like symptoms or a history of thrombosis are not present the chance of finding antiphospholipid antibodies or antinuclear antibodies is comparable with that in a control population of women with normal obstetric histories.

This study was supported by a grant from the Praeventiefonds (28-1511). The authors would like to thank all specialists in the Netherlands who sent blood samples of their patients for antiphospholipid antibody screening.

1 Harris E N, Asherson R A, Hughes G R V. Antiphospholipid antibodies-autoantibodies with a difference. Annual Review of Medicine 1988; 39: 261-71.

2 Derksen R H W M, Kater L. Lupus anticoagulant: revival of an old phenomenon. Clin. Exp Rheumatol 1985; 3: 349-57.

3 Barbui T, Radici E, Cortelazzo S, et al. Antiphospholipid antibodies in early repeated abortions: a case-controlled study. Fertil Steril 1988; 50: 589-92.

4 Carreras L O, Vermijlen J, Spitz B, Van Assche A. "Lupus" anticoagulant and inhibition of prostacyclin formation in patients with repeated abortion, intrauterine growth retardation and intrauterine death. Br $\mathcal{F}$ Obstet Gynaecol 1981; 88: 890-4.

5 Cowchock S, Smith B, Gocial B. Antibodies to phospholipids and nuclear antigens in patients with repeated abortions. Am $\mathcal{J}$ Obstet Gymecol 1986; 155: 1002-10.

6 Edelman Ph, Rouquette A M, Verdy E, et al. Autoimmunity, fetal losses, lupus anticoagulant: Beginning of systemic etal losses, lupus ancicoagulant. Beginning of systemic upus erythematosus or new autoimmune entity with gynaeco- 7 .

7 Howard M A, Firkin B G, Healy D L, Choong S C C. Lupus anticoagulant in women with multiple spontaneous miscarriage. Am f Hematol 1987; 26: 175-8. 
8 Maier D B, Parke A. Subclinical autoimmunity in recurrent aborters. Fertil Steril 1989; 51: 280-5.

9 Petri M, Golbus M, Anderson R, Whiting-O'Keefe Q, Corash L, Hellmann D. Antinuclear antibody, lupus anticoagulant, and anticardiolipin antibody in women with idiopathic habitual abortion. Arthritis Rheum 1987; 30: 601-6.

10 Tincani A, Cattaneo R, Martinelli M, et al. Antiphospholipid antibodies in recurrent fetal loss: only one side of the coin? Clin Exp Rheumatol 1987; 5: 390-1.

11 Unander A M, Norberg R, Hahn L, Arfors L. Anticardiolipin antibodies and complement in ninety-nine women
with habitual abortion. Am $\mathcal{f}$ Obstet Gynecol 1987; 156: with h.

12 Derksen $R$ H W M, Out $H$ J, Bruinse $H$ W, Christiaens G C M L, Van Vliet M, De Groot Ph G. Drug treatment in pregnant women with antiphospholipid antibodies. A preliminary report of a prospective study [Abstract]. Clin Exp Rheumatol 1990; 8: 219

13 Tan E M, Cohen A S, Fries J F, et al. The 1982 revised criteria for the classification of systemic lupus erythematosus. Arthritis Rheum 1982; 25: 1271-7.

14 Harger J H, Rabin B S, Marchese S G. The prognostic value of antinuclear antibodies in women with recurrent pregnancy losses: a prospective controlled study. Obstet Gynecol nancy losses: a prosp
1989; 73: 419-24.

15 El-Roeiy A, Myers S A, Gleicher N. The prevalence of autoantibodies and lupus anticoagulant in healthy pregnant women. Obstet Gymecol 1990; 75: 390-6.

16 Harris E N, Spinnato J. Anti-cardiolipin screening of healthy pregnant women is not a useful predictor of pregnancy outcome [Abstract]. Clin Exp Rheumatol 1990; 8: 220.
17 Derksen R H W M, Hasselaar P, Blokzijl L, Gmelig Meyling F H J, Groot de Ph G. Coagulation screen is more specific than the anticardiolipin antibody ELISA in defining thrombotic subset of lupus patients. Ann Rheum Dis 1988; 47: $364-71$.

18 Harris E N, Gharavi A E, Patel S P, Hughes G R V. Evaluation of the anticardiolipin antibody test: report of an international workshop held 4 April 1986. Clin Exp

19 Tan E M. Relationship of nuclear staining patterns with precipitating antibodies in systemic lupus erythematosus. f Lab Clin Med 1967; 70: 800-5.

20 Kurata N, Tan E M. Identification of antibodies to nuclear acidic antigens by counterimmunoelectrophoresis. Arthritis Rheum 1976; 19: 574-80.

21 Aarden L A, Groot de E R, Feltkamp T E W. Immunology of DNA. III. Crithidia luciliae, a simple substrate for the determination of anti-dsDNA with the immunofluorescence technique. Ann NY Acad Sci 1979; 254: 505-9.

22 Lubbe W F, Butler W S, Palmer S J, Liggins G C. Fetal survival after prednisone suppression of maternal lupusanticoagulant. Lancet 1983; i: 1361-3.

23 Branch D W, Scott J R, Kochenour N K, Hershgold E Obstetric complications associated with the lupus antiObstetric complications associated with the

24 Cowchock S, Fort J, Munoz S, Norberg R, Maddrey W. False positive ELISA test for anticardiolipin antibodies in sera from patients with repeated abortion, rheumatologic disorders and primary biliary cirrhosis: correlation with elevated polyclonal IgM and implications for patients with repeated abortion. Clin Exp Immunol 1988; 73: 289-94. 